\title{
ISSN 2088-1045
}

\section{Jurnal

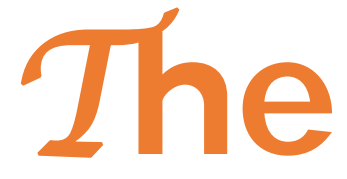 \\ Way}

Volume 5 | Nomor 1 | April 2019

\section{KAJIAN TENTANG RASA KHAWATIR PADA KEHIDUPAN "ORANG PERCAYA" DALAM PERSPEKTIF ALKITAB}

\author{
Renti Sihombing - rrenti1989@yahoo.com \\ Eddy Rundjan - edi.rundjan@gmail.com* \\ *Dosen Teologi STTB The Way
}

\begin{abstract}
Abstrak
Adapun tujuan penelitian ini, untuk menganalisis apa yang menjadi penyebab kekhawatiran kehidupan manusia. Memahami dan mengerti tentang makna kekhawatiran yang dialami orang percaya dan cara menanggulanginya. Selain itu dapat bermanfaat bagi pembaca untuk semakin menyadari bagaimana mengelola rasa khawatir dalam kehidupan. Instrumen penelitian yang digunakan adalah Literatur Studi Alkitabiah, yaitu mencari dukungan dari ayat-ayat Alkitab yang membahas tentang kekhawatiran. Kemudian dikaji kembali secara teologis. Hasil penelitian ini menyimpulkan bahwa Kristus memerintahkan agar orang percaya tidak perlu khawatir tentang hidupnya, tentang apa yang akan dia makan minum dan pakai, serta tidak perlu khawatir tentang masa depan (Mat. 6:25-34). Kekhawatiran tidak akan menyelesaikan masalah-masalah yang sedang dihadapi (Mat. 6:27). Pada ayat 27, Tuhan Yesus ingin menegaskan bahwa kekhawatiran itu tidak berguna. Jadi dapat disimpulkan bahwa mental dan pemikiran "orang percaya" perlu dilatih dalam hal percaya diri, berpikir positif, berusaha sebaik mungkin apapun hasil yang diterima, penguasaan diri dan tidak perlu khawatir.
\end{abstract}

Kata kunci: Rasa Khawatir, Kehidupan, Orang percaya, Alkitab

The purpose of this study is to analyze what is the cause of concern for human life. Understand and understand the meaning of the concerns experienced by believers and how to overcome them. In addition, it can be useful for readers to be more aware of how to manage their worries in life. The research instrument used in this study is Biblical Study Literature, namely seeking support from Bible verses that discuss concerns. Then it is reviewed theologically. The results of this study conclude that Christ commands that believers do not need to worry about their lives, about what they will eat and drink, and do not need to worry about the future (Matt. 6:25-34). Concern will not solve the problems at hand (Matt. 6:27). In verse 27, the Lord Jesus wants to emphasize that worry is useless. So it can be concluded that the mentality and thoughts of "believers" need to be trained in terms of self-confidence, positive thinking, trying to do whatever they can, self-mastery and not to worry.

Keywords: Worry, Life, Believers, the Bible

\section{Pendahuluan}

Alkitab dalam kitab Matius 6:24 menjelaskan bahwa seseorang tidak bisa mengabdi kepada dua tuan yaitu kepada Allah dan kepada Mamon. Kecenderungan manusia adalah ketika sudah mempunyai banyak harta, manusia sering lupa untuk bersyukur kepada sang pemberi harta itu, bahkan ketika 
manusia mempunyai lebih banyak harta maka kekhawatiran akan semakin besar. Dalam Perjanjian Baru, istilah yang dipakai untuk kata khawatir adalah merimnao, artinya "merasa cemas, kalut, pikiran bercabang". Itulah kata yang dipakai Yesus ketika Dia berkata, "Janganlah khawatir akan hidupmu" (Mat. 6:25). Paulus juga menggunakannya ketika ia menulis, "Janganlah hendaknya kamu khawatir tentang apapun juga" (Flp. 4:6). Orang-orang yang diliputi kekuatiran hanyut dalam kekuatirannya dan merasa kalut.

Bukankah manusia adalah ciptaan Allah dan la menopang keberlangsungan kehidupannya? Inilah fakta yang tidak dapat disangkali. Manusia adalah ciptaan yang mendapat jaminan dari Sang Pencipta, termasuk dengan halhal yang setiap hari diperlukannya. Dengan kata lain hidupnya adalah tanggung jawab Allah sepenuhnya. Jadi jika Allah sudah bertanggung jawab atas hal yang lebih besar, mengapa orang percaya enggan mempercayakan hidupnya kepadaNya.

\section{Rumusan Masalah}

1. Apa yang dimaksud dengan kekuatiran?

2. Bagaimana orang percaya mengelola kehidupan yang baik menurut prinsip-prinsip Alkitab?

\section{Ajaran Yesus Tentang Kekhawatiran}

Tuhan Yesus mengetahui bahwa manusia sering kuatir; jika nanti tidak ada makanan, minuman, dan pakaian. Kekuatiran dapat menjadi berlebihan dan dapat menjadi semacam penyakit. Para ahli ilmu jiwa tahu bahwa kekuatiran dapat menekan jiwa berjuta-juta orang, akibatnya orang tidak bisa tidur, sehingga kekuatiran kadang-kadang disebut "penyakit utama" dan "musuh utama manusia".

Manusia terlahir dengan kapasitas untuk cenderung kepada hal-hal rohani dan dengan kebutuhan untuk menyembah Allah. Manusia diciptakan dari elemenelemen materi dan memiliki kebutuhan materi serta kapasitas untuk menikmati hal-hal materi. Beberapa orang Kristen memiliki kekayaan materi yang berlimpah. Apakah fakta ini sendiri membuktikan bahwa mereka materialistis dan kurang rohani? Sebaliknya, apakah orang yang miskin lebih kecil kemungkinannya untuk menjadi materialistis dan lebih besar kemungkinannya untuk cenderung kepada hal-hal rohani?

Yesus mengingatkan murid-muridNya agar tidak menjadi kuatir. Apa yang menjadi fokus perhatian seseorang menjadi hal yang penting untuk diperhatikan; dan Yesus pun mengingatkan hal itu. "Hidup itu lebih penting dari makanan, dan tubuh lebih penting dari pakaian." Manusia takut tidak bisa makan, tapi seharusnya bersyukur ketika ia masih hidup. Manusia takut tidak sanggup membeli pakaian, tapi seharusnya bisa mensyukuri bahwa manusia itu masih punya tubuh. Manusia sering memandang hanya kepada masalah dan lupa memperhatikan apa yang masih dimilikinya. Manusia cenderung lebih melihat sisi negatif dari pada fokus kepada hal-hal positif dalam hidupnya; dan Yesus pun mengingatkan hal ini.

Sungguh amat sukar mematahkan daya tarik hedonisme dan materialisme. Di sinilah Yesus hadir untuk membantu orang percaya agar dapat bertindak dan membuat pilihan yang tepat. Yesus mengutarakan kepada orang percaya tentang bahaya dari sebuah pilihan yang tidak tepat atau tidak bijaksana. Berhadapan 
dengan ambisi manusia yang ingin mengatur hidupnya sendiri, Yesus menempatkan yang palsu dan yang sejati secara bertolak belakang sedemikian rupa sehingga menjadi momentum di mana orang percaya dapat menarik kesimpulan sendiri dan bertanggungjawab atas hidup mereka.

Sangat disayangkan bahwa Matius 6:25-34 sering di interpretasikan secara dangkal, sehingga makna perkataan yang dikatakan oleh Yesus yakni "Aku berkata kepadamu", menjadi kehilangan arti. Maksud perkataan Yesus tersebut ialah untuk memberikan pesan kepada orang percaya supaya matang dalam berpikir sebelum ia bertindak. Di satu sisi ungkapan "carilah" yang dipakai Yesus (yang mempertentangkan apa yang dicari oleh bangsa-bangsa yang tidak mengenal Allah dengan apa yang dicari oleh para pengikut-Nya) membawa orang percaya kepada pembicaraan tentang hal keutamaan atau dapat juga dikatakan sebagai ambisi positif. Yesus bertolak dari asumsi bahwa semua orang adalah "pencari". Manusia memerlukan tujuan untuk mengarahkan orientasi hidupnya, yakni sesuatu yang bakal memberikan makna kepada keberadaannya, yaitu sesuatu yang bernilai.

\section{Metode Penelitian}

Metode penelitian yang digunakan adalah Metode Kualitatif Deskriptif, ${ }^{1}$ Studi Pustaka, dan Studi alkitabiah. Instrumen penelitian yang digunakan dalam penelitian ini dikelompokkan dalam dua bagian, yaitu: Literatur (Buku-buku yang berbicara mengenai kekuatiran secara umum dan dalam hidup orang percaya). Studi alkitabiah yaitu mencari dukungan dari ayat-ayat Alkitab yang berbicara tentang kekhawatiran, kemudian dikaji secara teologis.

\section{Hasil Penelitian}

Iman

Iman adalah landasan atau dasar kepercayaan orang Kristen, substansi dari hal-hal yang diharapkan dan bukti dari hal-hal yang tidak kelihatan. Dalam Ibrani 11:1 dikatakan bahwa: "Iman adalah dasar dari segala sesuatu yang kita harapkan dan bukti dari segala sesuatu yang tidak kita lihat". Iman itu penting sejak awal kehidupan kekristenan dan itu berjalan bersamaan. Kehidupan didalam Kristus tidak mungkin tanpa iman. Orang Kristen harus mempunyai iman, karena iman membuka mata rohani untuk melihat apa yang tidak dapat dilihat oleh mata jasmani dan tidak dapat dirasakan secara fisik.

Supaya berhasil menjalani kehidupan Kristen, orang percaya harus melengkapi diri dengan perlengkapan senjata Allah. Instruksi ini ada dalam firman Tuhan supaya sebagai anak Allah, orang percaya mengerti dan mempelajari betapa pentingnya persiapan (Ef. 6). Tidak ada tentara yang pergi berperang tanpa terlebih dahulu mempersiapkan dirinya untuk melawan musuh tanpa menjadi korban.

Perlengkapan senjata Allah yang tersedia bagi orang percaya untuk digunakan dirinci dalam Efesus 6. Pasal ini berbicara mengenai ketopong dan pedang, baju zirah yang menutupi tubuh dan kasut, namun khususnya perisai

6.

\footnotetext{
${ }^{1}$ Lexy J. Moleong, Metodologi Penelitian Kualitatif (Bandung: Remaja Rosdakarya, 2014),
} 
iman. Alkitab berkata agar "diatas semuanya" kenakanlah perisai iman, yang menunjukkan bahwa iman merupakan senjata yang paling penting. ${ }^{2}$

Iblis tahu bahwa Allah telah memberikan banyak janji kepada orang percaya. Allah mencukupkan segala kebutuhan umatNya dan memberikannya bahkan lebih dari cukup sehingga bisa menjadi berkat bagi orang lain. Iblis mengetahui hal ini dan ia juga tahu bahwa melalui iman, seseorang bisa menerima segala janji Allah. Musuh mengetahui hal ini, ia menaruh keragu-raguan dan ketidak percayaan dalam diri orang percaya untuk mencuri janji-janji Allah itu. Orang-orang Kristen harus bangkit dan menyadari bahwa keadaan tidak berdaya muncul karena mereka tidak mengaktifkan dan mempraktekkan iman mereka. Yakobus berkata bahwa iman tanpa perbuatan adalah mati (Yak. 2:26). Seseorang bisa saja mempunyai iman yang besar, namun bila tidak membuat iman itu bekerja, iman itu adalah mati. ${ }^{3}$

Iman sangat dibutuhkan untuk menjalani kehidupan Kristen. Pada awalnya, segala sesuatu yang dicipatakan Allah itu baik adanya. Tetapi iblis menyelewengkannya sehingga manusia terpengaruh dan kehilangan iman kepada Allah. Iman itu berasal dari Allah. Allah menciptakan iman dan memberikannya kepada manusia karena iman itu baik. Musuh tahu bahwa iman itu baik dan ia berusaha menyelewengkannya. Iman tentunya bukan sekedar sebuah doktrin Perjanjian Baru saja, karena salah seorang nabi Perjanjian Lama pun menyatakan "orang yang benar itu akan hidup oleh iman (Hab. 2:4)". Kemudian didalam Perjanjian Baru, Paulus berkata di dalam Galatia 2:20 bahwa orang benar hidup dengan iman kepada Allah. Paulus juga berkata di dalam Roma 14:23 "segala sesuatu yang tidak berdasarkan iman, adalah dosa". Karena itu, segala sesuatu yang kita lakukan harus dilakukan di dalam iman, sebagai respon terhadap mandat Allah untuk melakukan suatu hal tertentu. ${ }^{4}$

Sebagaimana telah dibahas sebelumnya, iman adalah sebuah pemberian atau janji Allah kepada umatNya, kerena iman menghasilkan jawaban bagi kebutuhan-kebutuhan manusia, maka sesungguhnya Tuhan Yesus-lah yang menyediakan iman bagi kebutuhan-kebutuhan tersebut. Tuhan adalah penyedia, pencukup bagi keperluan umat-Nya. Karena itu, iman yang diperlukan untuk menyediakan kebutuhan-kebutuhan itupun dinyatakan melalui nama Tuhan yaitu Yehova Jireh. ${ }^{5}$ Pengalaman religius adalah suatu hubungan pribadi antara manusia dan Tuhan. Hubungan itu menggoncangkan, tetapi juga memberi kedamaian. R. Otto ${ }^{6}$ mengatakan bahwa hubungan manusia dengan yang kudus membuat manusia gemetar, segan dan takut. Ungakapan Otto yang terkenal adalah mysterium tremendum et Fascinosum yang berarti: Yang kudus yang membuat manusia gemetar, segan dan takut itu juga yang membuat manusia tertarik dan terdorong untuk menyatu dengan diri-Nya.

Pengalaman manusia dalam hubungannya dengan Tuhan sangat berbeda dengan pengalaman biasa. Hubungan dengan Tuhan mendorong manusia untuk mengambil sikap tertentu, antara lain senantiasa berkomunikasi dengan-Nya lewat doa dan pujian, beriman, meyerahkan diri, taat, mengasihi dan bergantung

\footnotetext{
${ }^{2}$ Raymond Mooi, Iman yang Bekerja (Semarang: Media Injil Kerajaan, 2005), 70.

3 Ibid., 33.

${ }^{4}$ Brian J. Bailey, Pilar-pilar Iman (Jakarta: Nafiri Gabriel, 1996), 23.

5 Ibid., 41.

${ }^{6}$ Koentjaraningrat, Sejarah Teori Antropologi (Jakarta: UI Pres, 1980), 65.
} 
kepada-Nya. ${ }^{7}$ Marthin Luther mendefenisikan iman sebagai "keyakinan yang hidup dan berani dalam kasih karunia Allah". Iman merupakan unsur penting dalam kehidupan yang baik sehingga disebut bahwa hubungan orang percaya dengan Allah sebagai "kehidupan iman". Salah satu janji yang paling besar yang ditulis dalam Alkitab ialah jaminan Yesus bahwa orang percaya yang mempunyai iman yang kecilpun berkenan kepada Allah. Bahkan dikatakan iman sekecil biji sesawipun merupakan sesuatu yang baik dan juga sangat kuat karena iman yang kecil itu dapat bertumbuh. Menurut Paulus, iman merupakan dasar keselamatan seseorang, yang penting ialah percaya bahwa Kristus telah membawa manusia ke dalam suatu hubungan yang benar dengan Allah Bapa yang penuh kasih dan pengampunan.

Penerapan iman secara spiritual, maka orang percaya perlu melakukan beberapa hal, yaitu: Berserah kepada Tuhan adalah menyerahkan seluruh jiwa dan raga di dalam tangan pengasihan-Nya. Berdoa kepada Tuhan tidak hanya dilakukan dalam hitungan jam, tetapi sepanjang hari itu tetap melibatkan Tuhan dalam segala hal. Saat jiwa seseorang mendapat hubungan yang penuh sepanjang waktu dengan Tuhan, niscaya dalam hidup seseorang itu akan bahagia dan dapat mendatangkan kebaikan kepada orang lain juga. Orang percaya yang memahami hal ini akan pasrah pada kehendak-Nya, harus bisa menempatkan diri di hadapan Tuhan dan di hadapan sesama manusia, sebab manusia hanyalah makhluk yang tidak sempurna dan tidak mungkin untuk mengendalikan segala sesuatu tentang apa yang harus dan tidak harus terjadi. Lebih baik jika manusia itu memasrahkan hidupnya di dalam Tuhan dan menghindari mendahulukan keinginan pribadi; Berjalan dalam kebenaran. Satu-satunya yang mengetahui dengan pasti apakah seseorang telah berjalan dalam kebenaran adalah Tuhan dan diri sendiri. Apabila seseorang nyaman dengan hal yang sedang dikerjakan, berarti itulah kebenaran. Akan tetapi, apabila setelah melakukan sesuatu yang dianggap benar tetapi hatinya tidak nyaman dan mengalami gelisah saat melakukannya berarti hal tersebut bukanlah kebenaran yang sejati; Mempunyai standar hidup yang baik; Alkitab adalah standar kehidupan bagi orang percaya dan sudah terbukti manjur semenjak ribuan tahun lalu. Janganlah kiranya buku yang sangat bermanfaat itu hanya menjadi pajangan semata, melainkan harus diaplikasikan setiap hari dan melakukan apa yang baik yang tertulis di dalamnya. Jangan membiarkan Kitab Suci itu hanya menjadi simbol dan tetap baru (seperti masih baru dibeli dari toko) karena tidak pernah digunakan sebelumnya; Mengikuti perkumpulan orang-orang beriman. Di dalam kegiatan rohani atau organisasi keagamaan yang baik, seseorang tidak dilatih untuk lebih dekat kepada Yang Maha Kuasa.

\section{Cara Berpikir}

Guna mengatasi rasa khawatir yang menyangkut banyak aspek kehidupan, ada banyak langkah-langkah yang harus dilakukan. Jika dikerjakan dengan tekun dan berusaha sebaik mungkin, maka kekhawatiran akan segera lenyap dari dalam kehidupan seseorang. Penerapan cara berpikir dan mental orang percaya perlu dilatih dalam beberapa hal, yaitu: Percaya diri. Yakin dengan diri sendiri itu tidak sama dengan sombong melainkan lebih kepada pikiran yang bebas dari keraguan.

\footnotetext{
${ }^{7}$ Jan Hendrik Rapar, Pengantar Filsafat (Yogyakarta: Penerbit Kanisius, 1996), 81.
} 
Jika seseorang percaya pada Yang Maha Kuasa maka dia akan berjalan dalam kehendak-Nya. Saat berada dalam kehendak-Nya berarti hidupnya dijamin olehNya, sehingga dalam segala sesuatu tidak ada lagi keraguan termasuk saat menyambut masa depan. Perlindungan orang percaya adalah Tuhan Yang Maha besar dan Maha hebat yang menyertai umat-Nya dalam kebenaran yang sejati; Luruskan pikiran untuk lebih positif. Bila terus berpikir bahwa hidup ini terancam, maka anggapan atau pendapat seperti itulah yang menakuti seseorang. Dalam membuat suatu pernyataan harus lebih berhati-hati sebab "kata-kata bisa saja menjadi kenyataan." Jangan membiarkan anggapan miring yang belum tentu kebenarannya meracuni pikiran. Pikiran positif menghasilkan perbuatan dan hasil positif pula. Berpikir positif adalah sumber kekuatan dan sumber kebebasan karena dapat membantu seseorang memikirkan solusi sampai mendapatkannya. Disebut sumber kebebasan karena dengannya seseorang akan terbebas dari penderitaan dan kekangan pikiran negatif serta pengaruhnya pada fisik. Saat pikiran sudah baik maka yang selanjutnya adalah perkataan, tindakan dan perbuatan sehari-hari pun akan menjadi baik. Banyak pekerjaan positif yang dapat dilakukan. Mulai dari hal-hal yang kecil sampai ke hal yang besar akan membawa dampak positif pula; Nilai-nilai Dasar Berpikir Positif. Pendidikan formal dan informal memegang peranan sangat penting dalam pembentukan kepribadian seseorang. Melalui pendidikan, seseorang dapat menumbuhkan benih-benih positif yang ada di dalam dirinya. Pendidikan juga memberi etika dan bekal moralitas kepada seseorang. Keduanya menjadi sarana menuju ke arah yang positif dan pendidikan merupakan faktor utama bagi kehidupan pribadi dan sosial.

Alasan mengapa Yesus melarang kuatir adalah:

1. Adanya jaminan pemeliharaan Bapa (ayat 32, Rom. 8:28). Orang percaya harus menyadari bahwa Tuhan telah menjadikannya sebagai anak-anak-Nya, dan Dia menjadi Bapanya. Sebagai anak, tidak mungkin Bapa membiarkan anak-anak-Nya untuk menanggung atau mengahadapi masalah seorang diri. Bapa yang baik, la pasti akan memberikan segala hal yang terbaik (Mat. 7:11). Dia berjanji akan memelihara dan menyertai anak-anak-Nya selamanya, jadi apa yang perlu di takutkan dan kuatirkan lagi.

2. Kekuatiran adalah musuh iman. Ketika Yesus menyuruh para murid untuk mendahului-Nya ke seberang dengan menggunakan perahu, sementara Yesus sendirian untuk berdoa di sebuah bukit. Para murid menghadapi masalah karena gelombang akibat angin sakal, maka saat itulah Yesus datang berjalan di atas air hendak menghampiri mereka, tetapi murid-murid mengira bahwa Dia adalah hantu. Kekuatiran dan kecemasan membuat mereka tidak lagi bisa melihat kemahakuasaan Allah atau mengkerdilkan kuasa Tuhan. Ketika Petrus melihat Yesus dan memohon untuk menghampiri Yesus dengan berjalan di atas air, dan akhirnya karena fokus Petrus hanya pada Yesus saat itu dan imannya mulai bangkit, maka iapun bisa berjalan di atas air, tetapi setelah beberapa langkah, dia mulai dihinggapi kekuatiran dan ketakutan, akibatnya imannya lemah dan hampir saja tenggelam (Mat. 14:22-32). Yesus melarang kuatir-karena kekuatiran hanya akan melemahkan iman.

Alkitab berisi janji-janji Allah bagi orang percaya dan janji-Nya adalah ya dan amin, karena itu jangan kuatir, orang yang kuatir adalah orang yang meragukan janji Tuhan dalam hidupnya. Menjadi pertanyaannya sekarang adalah, 
bagaimana seharusnya sikap orang percaya dan apa yang harus di lakukan ketika ada masalah, kesulitan, tantangan, padahal Yesus melarang kita kuatir. Tetap berserah (I Pet. 5:7). Menyerahkan setiap pergumulan dan masalah kepada Tuhan dan percaya bahwa la sanggup menolong tepat pada waktunya. Tetap berdoa (Flp. 4:6). Firman Tuhan menjanjikan apabila orang percaya meminta, maka dia akan mendapatkannya, jadi yang Tuhan inginkan adalah tetap berdoa dan hanya menantikan pertolongan dari Tuhan saja. Tetap bersyukur (I Tes. 5:18). Kehendak Tuhan adalah tetap mengucap syukur apapun keadaannya, jadi bukan hanya dalam keadaan baik-baik saja seseraong mengucap syukur, tetapi justru dalam kelemahan, dalam masalah, dalam tekanan seseorang dituntut untuk tetap mengucap syukur.

Tindakan

Kristus memerintahkan agar orang percaya tidak perlu kuatir tentang hidupnya, tentang apa yang akan dia makan minum dan pakai, serta tidak perlu kuatir tentang masa depan (Mat. 6:25-34). Berdasarkan yang dikatakan Tuhan Yesus ada beberapa alasan yang menjadikan orang tidak perlu kuatir, yaitu: Tidak perlu kuatir.

Tidak perlu kuatir karena orang percaya memiliki Allah Bapa yang Maha baik dan berkemurahan (Mat. 6:26, 28-30). Dalam ayat 26 ini, Tuhan Yesus menguatkan lagi kepercayaan kepada Bapa di Sorga dengan menggunakan contoh bagaimana Allah memelihara burung-burung itu. Walaupun burung itu tidak menjalankan menabur dan menuai, serta mengumpulkan dalam lumbung, namun binatang itu menerima makanan dari Tuhan. Kalau Tuhan memelihara binatang, apalagi anak-anak-Nya, la pasti memelihara mereka. Sebagai anak-anak Allah, kita mempunyai tempat yang lebih penting dan berharga daripada burung-burung itu.

Kasih Allah Bapa yang memelihara

Dalam ayat 28-32, Tuhan Yesus mengambil contoh "bunga bakung di ladang" untuk melukiskan kasih Allah Bapa yang memelihara. Sebenarnya, Bunga Bakung yang dimaksudkan disini kemungkinan besar adalah bunga anemone, yang banyak sekali di lereng gunung pada bulan Februari dan Maret di Palestina, dengan warnanya yang ungu, sama dengan pakaian kebesaran seorang raja. Kemudian yang dimaksud dengan "rumput" dalam ayat 30 mengacu pada bungabunga anemone itu. Jadi, apa yang dimaksud dalam ayat 29 merujuk kepada Raja Israel Salomo yang terkenal akan kekayaannya, bunga anemone yang begitu singkat umurnya, dan yang tidak lama kemudian ikut terpotong bersama rumput yang dipakai sebagai bahan bakar untuk memenuhi kebutuhan manusia (lihat Yak. 1:11). Bunga itu, kata Yesus, mempunyai "pakaian" lebih indah daripada raja Salomo. Semuanya itu, karena Allah yang menghiasinya; karena bunga itu tidak bekerja dan tidak memintal untuk memperoleh "pakaian" tersebut. Jadi, jikalau Tuhan sedemikian rupa memelihara bunga yang dianggap sebagai tidak berharga, maka pastilah Bapa di Sorga akan memberi pakaian kepada anak-anak-Nya yang percaya akan Dia dan yang mau taat kepada-Nya.

Kekuatiran tidak pernah menyelesaikan masalah-masalah yang sedang dihadapi (Mat. 6:27). Pada ayat 27, Tuhan Yesus ingin menegaskan bahwa kekuatiran itu tidak berguna. Walau makanan itu penting bagi pertumbuhan 
seseorang, tetapi pertumbuhan itu sendiri Allah-lah yang mengendalikan. Waktu seorang anak bertumbuh menjadi dewasa. Allah menambahkan jauh lebih

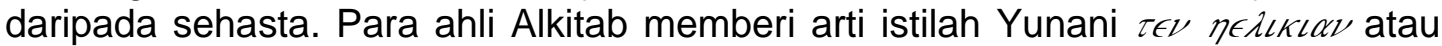
"tinggi badan" tersebut dengan pengertian "umur". Sedangkan kata Yunani: ПК $\eta \nu \nu$ $\eta \epsilon \nu \alpha$ atau "satu hasta" diartikan sebagai ukuran waktu (bukan ukuran tinggi badan). Naskah asli Yunani disini sebenarnya diterjemahkan menjadi "dengan kekuatiran, kamu tidak dapat menambahkan satu hasta pada ketinggian badanmu". Jarang ada orang yang ingin supaya tingginya bertambah dengan satu hasta, maka kebanyakan Ahli kitab menganggap "hasta" sebagai waktu tambahan kepada umur. Demikian jelaslah bahwa dengan kekuatiran, kehidupan manusia tidak dapat diperpanjang.

Ringkasnya, kekuatiran tidak membantu kesulitan esok hari, tetapi benarbenar merusak kebahagiaan. Semakin seseorang kuatir semakin sulit dan berat kehidupan yang dia jalani karena itu jangan pernah membiarkan kekuatiran mengarahkan hidup. Sehari penuh kekuatiran lebih melelahkan ketimbang sehari penuh bekerja. Jika seseorang tidak dapat menghindar dari rasa kuatir, mak perlu diingat bahwa kuatir juga tidak akan pernah membantunya. Pilihan untuk tidak kuatir adalah sikap percaya dan ketaatan pada perintah Tuhan Yesus. Tuhan memberikan perintah kepada umat-Nya untuk tidak kuatir. Berulang-ulang la mengingatkan umat-Nya akan perintah tersebut yang mengatakan "janganlah kamu megkuatirkan hidupmu! (Yunani: $\mu \epsilon \mu \epsilon \iota \mu \nu \alpha \tau \epsilon \tau \epsilon \pi \sigma v \kappa \eta \epsilon ~ \eta \nu \mu o \nu$; Mat 6:25). Tuhan mengajarkan agar orang percaya menyerahkan segala keinginannya kepada-Nya dalam doa dan permohonan dengan ucapan syukur (Flp. 4:6).

Cara Mengatasi Kekhawatiran

Percaya dan berserah kepada Tuhan

Perhatikan frasa "hai orang yang kurang percaya" dalam ayat 30 ini adalah

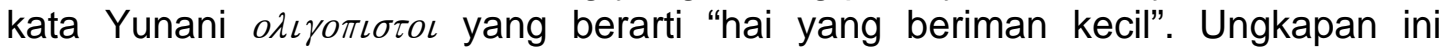
dipergunakan 4 kali dalam Injil Matius, satu kali dalam Injil Lukas, sebagai dorongan pertumbuhan maupun tegoran yaitu "jangan menjadi orang yang kurang percaya!" atau "jangan menjadi kuatir dan gelisah!" Sementara, bangsa-bangsa yang tidak mengenal Allah hidup dalam kekuatiran karena mereka tidak mengenal Bapa di Sorga; tidaklah demikian dengan orang-orang percaya yang mengenal Allah, Bapa yang mengetahui kebutuhan anak-anakNya dan dengan murah hati memberikannya.

Kata Yunani "dicari" dalam ayat 32 adalah $\epsilon \pi \iota \zeta \epsilon \tau \in \iota$ yang berarti "berusaha keras mencari" yang bermakna "pencarian sekuat tenaga dengan kerja keras dan beban berat". Orang-orang yang tidak mengenal Allah mengejar meteri karena kekuatiran mereka dengan cara $\epsilon \pi \iota \zeta \epsilon \tau \epsilon \iota$ ini. Tuhan tidak menginginkan anak-anakNya mengejar materi dengan cara seperti orang-orang yang tidak mengenal Allah tersebu. Tuhan mau supaya orang percaya mendahulukan mencari kerajaan-Nya dan kebenaran-Nya. Saat orangn percaya melakukannya, semuanya itu akan ditambahkan kepadanya. Tetaplah percaya dan setia pada Tuhan. Pemazmur mengatakan "Serahkanlah hidupmu kepada Tuhan dan percayalah kepada-Nya, dan la akan bertindak" (Maz. 37:5). Ketika seseorang tidak memiliki apapun, selain Tuhan, itu cukup baginya, karena memang hanya Dia yang di perlukan! seseorang akan selalu mengalami kesulitan jika berusaha mengatasi masalah hidupnya tanpa Tuhan. Carilah Dia dengan segenap hati. 
Mencari kerajaan Allah dan Kebenarannya

Tuhan Yesus mengatakan: "Carilah (lebih) dahulu Kerajaan Allah dan

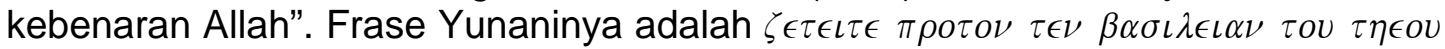

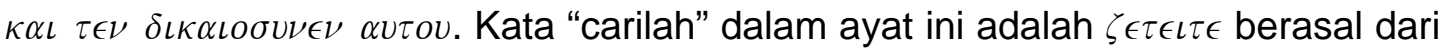
kata $\zeta \epsilon \tau \epsilon O$ yang yang berarti "mencari" adalah bentuk kata kerja aktif yang bermakna "menunjuk terjadinya keasyikan terus-menerus ketika mencari sesuatu; berusaha dengan sungguh-sungguh dan tekun untuk memperoleh sesuatu". Kata Yunani untuk kata "dahulu" dalam ayat 33 ini adalah "proton" yang berarti "pertama dalam urutan atau kepentingan; menempati tempat yang tertinggi dari semua kesenangan manusia". Ini artinya, orang percaya diminta untuk mendahulukan Kerajaan Allah dan kebenaran-Nya diatas segala hal. Jadi prioritas pertama dan utama orang percaya setiap hari adalah mencari kerajaan Allah dan kebenaran-Nya. Saat oranng percaya melakukannya, maka dia akan mengalami "panta prostethêsetai humin", yaitu "semua akan diberikan dan ditambahkan kepadamu". Kata Yunani $\pi \rho \circ \sigma \tau \iota \tau \eta \epsilon \mu \iota$ dapat diterjemahkan dengan "diberikan" atau "ditambahkan". Kedua arti tersebut, baik "diberikan" maupun "ditambahkan" dapat di pergunakan secara bersama-sama. Hal ini dapat dipahami karena Allah yang mengetahui kebutuhan umat-Nya, la juga akan menyediakan, memberikan, dan menambahkan apa yang diperlukan baik jasmani maupun rohani (Bandingkan 2 Kor. 9:8).

Lalu, apakah yang dimaksud dengan "mencari kerajaan Allah dan

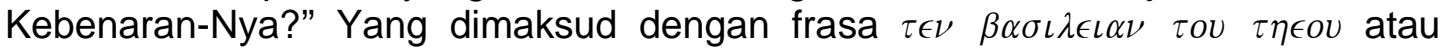
"kerajaan Allah" adalah otoritas dan pemerintahan Allah. Orang percaya harus menempatkan sungguh-sungguh kepemimpinan, otoritas dan supremasi Allah dinyatakan melalui kehidupannya. Dengan mencari kerajaan Allah berarti bahwa seseorang hendak melakukan dan memberlakukan kehendak dan otoritas Allah dalam setiap aspek kehidupannya. Sedangkan kata $\tau \epsilon \nu \delta \iota \kappa \alpha \iota o \sigma \nu \nu \epsilon \nu$ $\alpha \nu \tau o v$, atau "kebenaran-Nya" disini berkaitan dengan sifat atau karakter yang ada pada Allah. Mencari kebenaran disini berarti berkata, bertindak dan bertingkah laku yang sesuai dengan karakter Allah. Pertama-tama kebenaran yang di cari adalah kedudukan yang benar dihadapan Allah melalui anugerah yang telah di terima dalam Kristus (Rom. 5:17). Kedua, dengan augerah-Nya, tetap berpegang pada kebenaran melalui kasih dan ketaatan kepada Allah (Ef. 4:16). Dengan demikian, mencari dahulu kerajaan Allah dan kebenaran-Nya berarti mengutamakan dan memberlakukan terus menerus supremasi dan perintah Allah dalam hidup orang percaya. Menempatkan Allah sebagai yang pertama dan terutama, berarti merelakan Dia memerintah atas hidup umat-Nya.

Tuhan mengetahui bahwa didalam kehidupan kita masing-masing setiap hari ada persoalan, baik itu kecil atau besar, harus di hadapi dengan pertolongan Tuhan. Jika seseorang mengkuatirkan hari esok, maka bebannya justru akan bertambah. Disini, seseorang akan mendapat pelajaran yang berharga dari Yesus Kristus, agar "Janganlah kuatir tentang apapun juga". Hal yang sama juga dikatakan Paulus "Janganlah hendaknya kamu kuatir tentang apa pun juga, tetapi nyatakanlah dalam segala hal keinginanmu kepada Allah dalam doa dan permohonan dengan ucapan syukur" (Fil. 4:6). Demikian juga dengan Petrus yang menasihati supaya "Serahkanlah segala kekuatiranmu kepada-Nya, sebab la yang memelihara kamu" (1 Pet. 5:7). 


\section{Pembahasan}

Berdasarkan penjelasan diatas, maka kekuatiran dapat dijelaskan dari berbagai perspektif, antara lain: perspektif psikologi, perspektif sosiologi, perspektif ekonomi dan pengajaran Tuhan Yesus.

\section{Perspektif Psikologi}

Perspektif adalah sudut pandang atau pandangan,, ${ }^{8}$ sedangkan "Psikologi" berasal dari perkataan yunani psyche yang artinya adalah jiwa, dan logos yang artinya ilmu pengetahuan. Jadi secara etimologi (menurut kata) psikologi artinya adalah ilmu yang mempelajari tentang jiwa, baik mengenai macam-macam gejalanya, prosesnya, maupun latar belakangnya. Sepanjang hidupnya seseorang selalu mengalami berbagai kebutuhan yang harus dipenuhi, supaya ia dapat bertahan hidup. Secara berangsur-angsur ia memperoleh cara-cara dalam memuaskan kebutuhan-kebutuhan tersebut dan menjadi suatu kebiasaan. Kebutuhan-kebutuhan dan kebiasaan dalam cara memuaskan untuk memenuhinya dapat dilihat oleh orang lain dan itu disebut kepribadian. Kepribadian sering digambarkan sebagai pola keseluruhan tingkah laku seseorang pada setiap tahap perkembangannya. Kepribadian dapat dikatakan mencakup semua aspek-aspek perkembangan, seperti perkembangan fisik, motorik, mental, sosial, moral. Kepribadian merupakan suatu kesatuan aspekaspek jiwa dan badan, yang menyebabkan adanya kesatuan dalam tingkahlaku dan tindakan seseorang. Ini disebut integrasi, intergrasi dari pol-pola kepribadian yang dibentuk oleh seseorang, dan pembentukan pola kepribadian ini adalah melalui suatu proses interaksi di dalam dirinya sendiri, dengan pengaruhpengaruh dari lingkungan luar. ${ }^{9}$

\section{Pengertian Kecemasan}

Kecemasan atau dalam Bahasa Inggrisnya "anxiety" berasal dari Bahasa Latin "angustus" yang berarti kaku, dan "ango, anci" yang berarti mencekik. Menurut Freud mengatakan bahwa kecemasan adalah fungsi ego untuk memperingatkan individu tentang kemungkinan datangnya suatu bahaya sehingga dapat disiapkan reaksi adaptif yang sesuai. Kecemasan berfungsi sebagai mekanisme yang melindungi ego karena kecemasan memberi sinyal kepada kita bahwa ada bahaya dan kalau tidak dilakukan tindakan yang tepat maka bahaya itu akan meningkat sampai ego dikalahkan. ${ }^{10}$

Taylor mengatakan bahwa kecemasan ialah suatu pengalaman subjektif mengenai ketegangan mental yang menggelisahkan sebagai reaksi umum dan ketidakmampuan menghadapi masalah atau tidak adanya rasa aman. Perasaan yang tidak menyenangkan ini umumnya menimbulkan gejala-gejala fisiologis (seperti gemetar, berkeringat, detak jantung meningkat, dan lain-lain) dan gejalagejala psikologis (seperti panik, tegang, bingung, tak dapat berkonsentrasi, dan sebagainya). Perbedaan intensitas kecemasan tergantung pada keseriusan ancaman dan efekivitas dari operasi-operasi keamanan yang dimiliki seseorang.

\footnotetext{
${ }^{8}$ Kamus Bahasa Indonesia Perspektif, 760.

${ }^{9}$ Singgih D. Gunarsa, Psikologi Perawatan (Jakarta: Gunung Mulia, 2008), 68.

10 Ibid.
} 
Mulai munculnya perasaan-perasaan tertekan, tidak berdaya akan muncul apabila orang tidak siap menghadapi ancaman. ${ }^{11}$

Ada beberapa sumber-sumber Kecemasan, antara lain: Kecemasan yang berasal dari dalam diri seseorang (internal). Faktor internal adalah faktor yang berasal dari dalam diri orang itu sendiri. Faktor internal ini biasanya merupakan faktor genetis atau bawaan. Faktor genetis maksudnya adalah faktor yang berupa bawaan sejak lahir dan merupakan pengaruh keturunan dari salah satu sifat yang dimiliki oleh salah satu dari kedua orang tuanya atau bisa jadi gabungan atau kombinasi dari sifat kedua orang tuanya. Sering ada istilah "buah jatuh tidak akan jauh dari pohonnya". Misalnya, sifat mudah marah yang dimiliki oleh sang ayah bukan tidak mungkin akan menurun pula pada anaknya. Kecemasan yang berasal dari luar seseorang (eksternal). Faktor eksternal adalah faktor yang berasal dari luar orang tersebut. Faktor eksternal ini biasanya merupakan pengaruh yang berasal dari lingkungan seseorang, mulai dari lingkungan terkecilnya, yakni keluarga, teman tetangga, sampai dengan pengaruh dari barbagai media audiovisual seperti TV, VCD dan internet, atau media cetak seperti koran, majalah dan lain sebagainya. ${ }^{12}$

Dalam kehidupan sehari-hari seseorang, terus-menerus menyesuaikan diri dengan cara-cara tertentu, sehingga penyesuaian tersebut merupakan suatu pola. Biasanya seseorang dapat memenuhi dan memuaskan kebutuhannya dengan cara-cara yang dapat diterima oleh umum. Bila pemuasan kebutuhannya mengalami rintangan, maka ia akan mencari dan berusaha mencapai pemuasan tersebut dengan cara-cara yang tidak begitu diinginkannya, namun dengan cara yang tidak ditentang oleh umum. Seorang sejak kecil sudah harus membentuk pola-pola aktivitas dan sikap-sikap yang lain sesuai dengan keadaan baru, yang disebut penyesuaian. Pola-pola yang dibentuk kemudian disebut mekanisme penyesuaian. ${ }^{13}$ Beberapa ahli mempelajari jiwa atau psikis dan gejala-gejala yang diakibatkan oleh keberadaan psikis tersebut. Manusia menghayati kehidupan kejiwaan berupa kegiatan berfikir, berfantasi, mengingat, sugestif, sedih dan senang, berkemauan. Yang termasuk dalam gejala kejiwaan adalah gejala pengenalan (kognisi), gejala perasaan (emosi), gejala kehendak (konasi), dan gejala campuran (kombinasi) ${ }^{14}$.

Kecemasan Dalam Perspektif Psikologi

Kecemasan dialami ketika berfikir tentang sesuatu tidak menyenangkan yang akan terjadi. Sedangkan kecemasan sebagai suatu keadaan yang menggoncangkan karena adanya ancaman terhadap kesehatan. ${ }^{15}$ pengertian tentang kecemasan sebagai suatu keadaan emosional yang mempunyai ciri keterangsangan fisiologis, perasaan tegang yang tidak menyenangkan, dan kekuatiran bahwa sesuatu yang buruk akan terjadi. ${ }^{16}$ Kecemasan adalah rasa kuatir, takut yang tidak jelas sebabnya. Kecemasan juga merupakan kekuatan

${ }^{11}$ Carole Wade dan Carol Travis, Psikologi (Jakarta: Erlangga, 2000), 24.

12 Singgih D. Gunarsa, Psikologi Olahraga (Jakarta: BPK Gunung Mulia, 1996), 12.

13 Ibid., 105.

${ }^{14}$ Dimyati Mahmud, Psikologi Pendidikan (Jakarta: Depdikbud, 1989), 25.

${ }^{15}$ Siti Sundari, Kearah Memahami Kesehatan Mental (Yogyakarta: PPB FIP UNY, 2004), 62.

${ }^{16}$ Nevid, Jeffrey S., Rathus, Spencer A., dan Greene Beverly, Pengantar Psikologi Abnormal (Bandung: Erlangga, 2005), 163. 
yang besar dalam menggerakkan tingkah laku, baik tingkah laku yang menyimpang ataupun yang terganggu. Kedua-duanya merupakan pernyataan, penampilan, penjelmaan dari pertahanan terhadap kecemasan tersebut. ${ }^{17}$ Kesimpulan yang dapat diambil dari beberapa pendapat diatas bahwa kecemasan adalah rasa takut atau kuatir pada situasi tertentu yang sangat mengancam yang dapat menyebabkan kegelisahan karena adanya ketidakpastian dimasa mendatang serta ketakutan bahwa sesuatu yang buruk akan terjadi.

Gejala-gejala Kecemasan

Gejala-gejala yang bersifat fisik diantaranya adalah: jari tangan dingin, detak jantung makin cepat, berkeringat dingin, kepala pusing, nafsu makan berkurang, tidur tidak nyenyak, dada sesak. Gejala yang bersifat mental adalah: ketakutan merasa akan ditimpa bahaya, tidak dapat memusatkan perhatian, tidak tenteram, ingin lari dari kenyataan. ${ }^{18}$ Kecemasan juga memiliki karakteristik berupa munculnya perasaan takut dan kehati-hatian atau kewaspadaan yang tidak jelas dan tidak menyenangkan. Gejala-gejala kecemasan yang muncul dapat berbeda pada masing-masing orang. Takut dan cemas merupakan dua emosi yang berfungsi sebagai tanda akan adanya suatu bahaya.

\section{Dampak Kecemasan}

Rasa takut dan cemas dapat menetap bahkan meningkat meskipun situasi yang betul-betul mengancam tidak ada, dan ketika emosi-emosi ini tumbuh berlebihan dibandingkan dengan bahaya yang sesungguhnya, emosi ini menjadi tidak adaptif. Kecemasan yang berlebihan dapat mempunyai dampak yang merugikan pada pikiran serta tubuh bahkan dapat menimbulkan penyakit- penyakit fisik. $^{19}$

\section{Perspektif Sosiologi}

Sosiologi berasal dari bahasa Latin yaitu Socius yang berarti kawan, teman sedangkan Logos berarti ilmu pengetahuan. Ungkapan ini dipublikasikan diungkapkan pertama kalinya dalam buku yang berjudul "Cours De Philosophie Positive" karangan August Comte (1798-1857). Walaupun banyak definisi tentang sosiologi namun umumnya sosiologi dikenal sebagai ilmu pengetahuan tentang masyarakat. ${ }^{20}$ Masyarakat adalah sekelompok individu yang mempunyai hubungan, memiliki kepentingan bersama, dan memiliki budaya. Sosiologi hendak mempelajari masyarakat, perilaku masyarakat, dan perilaku sosial manusia dengan mengamati perilaku kelompok yang dibangunnya. Sebagai sebuah ilmu, sosiologi merupakan pengetahuan kemasyarakatan yang tersusun dari hasil-hasil pemikiran ilmiah dan dapat di kontrol secara kritis oleh orang lain atau umum.

Faktor-Faktor Masalah Sosiologi

Faktor-faktor emosi dan penyesuaian diri juga menjadi penyebab. Munculnya persoalan diri pribadi mengakibatkan tingkah laku yang menuju kepada kesendirian secara sosial atau keadaan emosi yang terganggu; mereka

\footnotetext{
17 Singgih D. Gunarsa, Psikologi Perawatan (Jakarta: Gunung Mulia 2008), 27.

18 Sundari, Loc. Cit.

${ }^{19}$ Cutler Howard C, Seni Hidup Bahagia (Jakarta: Gramedia Pustaka Utama, 2004), 304.

${ }^{20}$ Andreas Soeroso, Sosiologi (Jakarta: Perpustakaan Nasional, 2002), 19.
} 
mengalami lebih banyak kekuatiran dalam interaksi sosial dan bisa mengakibatkan tekanan mental yang menyebabkan frustrasi. ${ }^{21}$

Bentuk umum proses-proses sosial adalah interaksi sosial (yang juga dapat dinamakan proses sosial), oleh karena interaksi sosial merupakan syarat utama terjadinya aktivitas-aktivitas sosial. Interaksi sosial antara kelompok-kelompok manusa terjadi antara kelompok tersebut sebagai kesatuan dan biasanya tidak menyangkut pribadi anggota-anggotanya (Contoh: perang dunia).

Perspektif Ekonomi

Ilmu ekonomi adalah suatu studi ilmiah yang mengkaji bagaimana orang perorangan dan kelompok-kelompok masyarakat menentukan pilihan. Manusia mempunyai keinginan-keinginan yang tidak terbatas. Untuk memuaskan berbagai macam ragam keinginan tersebut, tersedia sumberdaya yang dapat digunakan. Berbagai sumber daya ini tidak tersedia dengan bebas. Pilihan penggunaan dapat terjadi antara penggunaan sekarang (hari ini) dan penggunaan hari esok (masa depan). Cakupan pilihan atas sumber daya yang tersedia meliputi pengunaan sekarang dan penggunaan masa depan. Selain itu, penggunaan sumber daya tersebut menimbulkan pula biaya dan manfaat. Mengingat adanya biaya dan manfaat, maka diperlukan pertimbangan efisiensi dalam penggunaan sumber daya. $^{22}$ Kekuatiran (akan uang, akan masa depan) mengakibatkan dampak yang buruk. Memulai dengan satu kalimat kekuatiran, manusia dapat berkhayal yang tidak-tidak dan sia-sia. Dikatakan sia-sia karena hampir semua kekuatiran tidak pernah terjadi.

\section{Masalah Ekonomi}

Mudah untuk mengucapkan bahwa manusia tidak perlu kuatir tentang hari esok, namun untuk menghadapinya tidaklah mudah. Ada banyak faktor yang membuat manusia kuatir. Tagihan, uang sekolah, krisis, kehilangan pekerjaan, masih banyak hal lain lagi adalah adalah beberapa contoh yang membuat manusia kuatir. Lingkungan sangat mempengaruhi keadaan emosi dan kekuatiran selalu mengejar manusia dan itu sangat sulit untuk dilepaskan. Untuk sekedar memikirkan apa yang manusia perlukan untuk masa depan mereka adalah tidak masalah. Pokok masalah yakni ketika apa yang dipikirkan itu menjadi suatu beban dan menjadi tidak sejahtera karenanya. Apakah manusia tidak perlu kuatir tentang tagihan bulanan yang masing-masing harus lunas tipa bulannya? Atau apakah dalam hal ini manusia juga tidak perlu kuatir tentang masalah yang terjadi dalam hubungan dengan sesama? Atau apakah termasuk didalamnya manusia tidak perlu kuatir tentang mimpi, cita-cita, tujuan hidup serta ambisi mereka masingmasing? Tentu saja, manusia perlu memikirkan itu semua. Yang perlu diperhatikan adalah jangan sampai seseorang menjadi susah karena menguatirkannya.

Perspektif Filsafat

Kata filsafat atau filosofi terdiri dari dua kata yaitu: philo (suka cinta) dan sophia (kebijaksanaan). Demikian filsafat dapat diartikan dengan cinta pada pengetahuan dan kebijaksanaan. Berangkat dari makna kata ini pula rujukan dari

\footnotetext{
${ }^{21}$ Ibid.

${ }^{22}$ Gerardo P Sicat dan H.W Arndt, IImu Ekonomi (Jakarta: LP3ES, 1991), 3.
} 
pengertian filsafat itu, seperti dalam bahsa inggris disebut "love of wisdom". ${ }^{23}$ Untuk menjelaskan kekuatiran dari perspektif filsafat, maka erat kaitannya dengan hedonisme, materialisme, konsumerisme dan individualisme. Pengaruh Teknologi juga mempengaruhi kehidupan seseorang dalam Membentuk Perilaku Dewasa yang Individual. Pengaruh yang timbul akibat dari perkembangan teknologi gaya hidup modern, gaya hidup malas, gaya hidup tidak sehat.

Alkitab Dalam Perspektif Perasaan Khawatir

Kata "khawatir" dalam ucapan Tuhan Yesus: janganlah kamu kuatir, diterjemahkan dari bahasa Yunani $\mu \epsilon \rho \mu \nu \alpha \tau \epsilon$. Istilah ini bukan untuk menggambarkan jenis kekuatiran yang normal, tetapi untuk kekuatiran yang neurotis. Berarti yang Yesus maksudkan adalah: janganlah kamu membiarkan diri kamu dikuasai oleh kekkuatiranmu, sehingga kamu terus menerus gelisah dan tidak mempunyai pengharapan. Seseorang bisa saja merasa kuatir, tetapi jangan membiarkan kekuatiran itu justru yang menguasai dirinya. Seseorang yang memiliki kekuatiran yang neurotis terhadap masa depan, secara tidak langsung meragukan karya pemeliharaan Tuhan dalam hidupnya.

Masa depan yang misterius memang bisa membuat seseorang merasa kuatir. Tetapi sebenarnya dia bisa menghadapi masa depan itu tidak dengan hati dan pikiran tegang. Untuk menyongsong masa depan itu seseorang tetap bisa bersabar dan berpikiran bahwa dia akan berusaha untuk hidup yang lebih baik dari sebelumnya. Tuhan Yesus menegaskan bahwa hidup manusia tidaklah tergantung dari kekayaan (Luk. 12:15). Orang yang bergantung pada kekuatan uang berarti memberhalakannya. Kalau seseorang sudah terikat dengan berhala kekayaan ini atau materialisme maka sangatlah sukar mengerti dan menangkap kebenaran firman Tuhan. Dalam hal ini bisa dipahami mengapa Tuhan Yesus berkata bahwa orang kaya sukar masuk ke dalam kerajaan sorga (Mark. 10:2427). Tipu daya kekayaan menunjuk pada ikatan terhadap harta, sehingga kebahagiaan jiwanya hanya dapat ditopang oleh kekayaan. Dalam hal ini harus diwaspadai bahwa kekayaan dapat memikat hati seseorang sehingga merasa tidak memerlukan yang lain. Tuhan pun juga tidak diperlukannya. Jika sudah demikian, maka ia tidak dapat menjadikan Tuhan Yesus Kristus sebagai Allah, sebab allahnya adalah kekayaan tersebut.

Orang Kristen harus berhati-hati untuk menghindari jerat gaya hidup yang berlebihan dan persoalan situasi ekonomi mereka. Kuasa kekayaan bersifat menipu dan dapat mencekik kerohanian (Mat. 13:22). Tidak diduga-duga, fokus seseorang bisa bergeser dari hal-hal rohani ke hal-hal materi, dengan konsekuensi yang menyedihkan (Ams. 28:20; Pkh. 5:10). Oleh karena itu, orang Kristen sebaiknya memeriksa prioritas dan fokus mereka dalam kehidupan rohani mereka. Tidak soal seseorang memiliki sedikit atau banyak materi, orang yang berpikiran rohani berupaya keras mengikuti peringatan rasul Paulus untuk menaruh harapan mereka "bukan pada kekayaan yang tidak pasti, tetapi pada Allah, yang memberikan segala sesuatu dengan limpah kepada umat-Nya untuk kesenangannya" (1 Tim. 6:17-19). Yesus dalam pengajarannya tentang bahagia dan kepuasan hidup yang tertulis di Matius 5:3 dan 6 mengatakan demikian: Ayat 3 "Berbahagialah orang yang miskin di hadapan Allah, karena merekalah yang

\footnotetext{
${ }^{23}$ H. Jalaludin, Filsafat IImu Pengetahuan (Jakarta: PT. Raja Grafindo Persada, 2013), 76.
} 
empunya Kerajaan Sorga." Ayat 6 "Berbahagialah orang yang lapar dan haus akan kebenaran, karena mereka akan dipuaskan."

\section{Kesimpulan}

Adanya jaminan pemeliharaan Bapa (ayat 32, Rom 8:28), orang percaya harus menyadari bahwa Tuhan telah menjadikannya sebagai anak-anak-Nya, dan Dia menjadi Bapanya. Orang percaya sebagai anak, tidak mungkin Bapa membiarkan anak-anakNya menanggung atau menghadapi masalah seorang diri. Allah sebagai Bapa yang baik, la pasti akan memberikan segala hal yang terbaik (Mat. 7:11). Dia berjanji akan memelihara dan menyertai anak-anak-Nya selamanya. Mental orang percaya perlu dilatih dalam hal percaya diri, berpikir positif, berusaha sebaik mungkin apapun hasilnya terima apa adanya, penguasaan diri, dan tindakan untuk tidak perlu khawatir

\section{Kepustakaan}

Bailey, Brian J. Pilar-pilar Iman. Jakarta: Nafiri Gabriel, 1996.

Gunarsa, Singgih D. Psikologi Olahraga. Jakarta: BPK Gunung Mulia, 1996. . Psikologi Perawatan. Jakarta: Gunung Mulia, 2008.

Howard, Cutler. Seni Hidup Bahagia. Jakarta: Gramedia Pustaka Utama, 2004.

Jalaludin. Filsafat IImu Pengetahuan. Jakarta: PT. Raja Grafindo Persada, 2013.

Tim Penyusun. Kamus Besar Bahasa Indonesia. Jakarta: Balai Pustaka, 2000. Koentjaraningrat. Sejarah Teori Antropologi. Jakarta: UI Press, 1980.

Mahmud, Dimyati. Psikologi Pendidikan. Jakarta: Depdikbud, 1989.

Moleong, Lexy J. Metodologi Penelitian Kualitatif. Bandung: Remaja Rosdakarya, 2014.

Mooi, Raymond. Iman yang Bekerja. Semarang: Media Injil Kerajaan, 2005.

Nevid, Jeffrey S. Dkk. Pengantar Psikologi Abnormal. Bandung: Erlangga, 2005. Sundari, Siti. Kearah Memahami Kesehatan Mental. Yogyakarta: PPB FIP UNY, 2004.

Soeroso, Andreas. Sosiologi. Jakarta: Perpustakaan nasional, 2002.

Sicat, Gerardo P dan H.W, Arndt. IImu Ekonomi. Jakarta: LP3ES, 1991.

Wade, Carole dan Travis, Carol. Psikologi. Jakarta: Erlangga, 2000. 